\title{
Passwords
}

Volume 12 | Issue 2

Article 10

6-4-2012

\section{Surreal Self Portrait}

Gabrielle Kelenyi

gik02009@mymail.pomona.edu

Follow this and additional works at: http://scholarship.claremont.edu/passwords

Part of the Creative Writing Commons

\section{Recommended Citation}

Kelenyi, Gabrielle (2012) "Surreal Self Portrait," Passwords: Vol. 12: Iss. 2, Article 10. DOI: 10.5642/passwrd.20121202.10 Available at: http://scholarship.claremont.edu/passwords/vol12/iss2/10

This Poetry is brought to you for free and open access by the Journals at Claremont at Scholarship @ Claremont. It has been accepted for inclusion in

Passwords by an authorized administrator of Scholarship @ Claremont. For more information, please contact scholarship@cuc.claremont.edu. 


\section{Surreal Self Portrait \\ Gabrielle Kelenyi}

No creo en las coincidencias:

Thus, half Puerto-Rican-half

German-and-Hungarian exorbitance.

I am a cultural experiment-

For I was raised by too many white folks

In a plush neighborhood of ignorance

And bliss

And boredom.

I am permeable and in excess;

Thus, I am myself y mi otra,

(a)live like ideas in auxiliary masks.

Hay una ineficaz de palabras de contenerme

Because I am ambiguous -

What does it mean to be exceptional?

"It's a condition."

Or is it a duration-

What does it mean to be recognizable, identifiable?

Words are (as) inaccessible, inacceptable.

Yo estoy terriblemente bendecida;

Or maybe I am inadequate.

What is a sense of self?

It's a way towards exits.

But am I defined by mis sueños, their dreams?

I am the production of happiness

From my parents

For my parents

On the mañana cálida I was born

The sky splintered into stars,

Watched me,

And dazzled,

As breathtaking as shiny knives.

My insides still tremor like poppies in the breeze

Es decir, con una maldita manía. 
My windswept mind:

Betrayed by deviance,

Saved only by the intervention of words

Spewing from absent eyes

under veils of sombras rotas.

The other day, I wanted to draw

A picture of a girl without the language

Of my brother in her ear,

Without the discrimination of dirt

Underneath her fingernails.

I wanted to arrange her outside

The confines of her names

Full of dubious hollows

(Like the worlds I write)

The savage shadows under my eyes never die

Por que todo lo hago bien

Except when my ravings burn into my genius

Then I just write. 